\title{
Dilema Kebijakan Penanganan Gelandangan Dan Pengemis Di Yogyakarta (Studi Kasus Perda DIY No. 1 Tahun 2014)
}

\section{Policy Dilemma To Handle Bummer And Beggars In Yogyakarta (Case Study DIY Perda No. 1 Year 2014)}

\author{
Jayyidan Falakhi Mawaza, Zaenuddin \\ Konsentrasi Islam Pembangunan dan Kebijakan Publik (IPKP) \\ Program Pascasarjana UIN Sunan Kalijaga Yogyakarta \\ email: jayyidanfm@gmail.com, alizainuddin02@gmail.com
}

\begin{abstract}
Abstrak
Artikel ini bertujuan untuk mengeksplorasi serta menganalisis dilema kebijakan yang terjadi di dalam Peraturan Daerah DIY No. 1 Tahun 2014 Tentang Penanganan Gelandangan dan Pengemis. Penelitian ini menggunakan pendekatan kualitatif yang analisis datanya dilakukan dengan metode observasi dan wawancara. Analisis data yang digunakan meliputi reduksi data, penyajian data dan penarikan kesimpulan. Di dalam Peraturan Daerah tersebut terdapat strategi penanganan yang cukup dilematis yakni strategi koersif dan preventif. Strategi koersif di dalam Perda ini, memiliki pasal-pasal yang cukup kontroversial seperti pemidanaan terhadap pengemis dan orang-orang yang memberi uang atau barang. Artikel ini mencoba membandingkan antara strategi koersif dengan strategi preventif serta dianalisis manakah strategi yang lebih efektif di dalam menanggulangi pengemis dan gelandangan. Untuk mengetahui hal tersebut, tentunya artikel ini mencoba melihat sejauh mana implemetasi yang dilakukan atas kedua strategi tersebut.
\end{abstract}

Kata Kunci: dilema; gelandangan; pengemis; perda

\begin{abstract}
This article aims to identify and analyze the policy dilemmas that occur in the Perda DIY No. 1 Year 2014 about the Handling Homeless and Beggars. This research used a qualitative approach that the data analysis is done by observation and interview. Analysis of the data used includes the step of data reduction, data presentation and conclusion. In the regional regulation are quite a dilemma copingstrategies that coercive strategies and preventive strategies. Coercive strategy in this regulation has chapters quite controversial as criminal prosecution against beggars and people who give money or goods. This article attempts to compare between a coercive strategy with preventive strategies and analyzed which strategies are more effective in tackling beggars and vagrants. To know that certainly written in the article tried to see the extent to which the implementation is done on the strategies.
\end{abstract}

Keywords: dilemma; homeless; beggars; perda

\section{Pendahuluan}

Berdasarkan data terbaru yang dirilis oleh Badan Perencanaan Pembangunan Daerah (Bappeda) Provinsi Daerah lstimewa Yogyakarta jumlah pengemis yang ada di Yogyakarta pada tahun 2019 sebanyak 134 orang. Sedangkan jumlah gelandangan sebanyak 190 orang (Bappeda Yogyakarta, 2019). Pengemis dan gelandangan digolongkan sebagai penyandang masalah kesejahteraan sosial (PMKS). Keberadaan pengemis dan gelandangan tidak lepas dari lingkaran kemiskinan yang mendera sebagian masyarakat 
sehingga menyebabkan tidak bisa diaksesnya kebutuhan-kebutuhan dasar (basic needs). Menjadi pengemis dan gelandangan bisa jadi merupakan pilihan terakhir dari masyarakat yang menderita kemiskinan untuk bertahan hidup.

Gelandangan sendiri secara bahasa dimaknai sebagai orang-orang yang menjalani kehidupan dalam keadaan yang tidak serasi dengan norma, nilai dan kehidupan layak dalam suatu lingkungan masyarakat. Istilah atau definisi gelandangan, berasal dari kata gelandang, yang memiliki makna orang yang selalu berkeliaran karena tidak memiliki tempat berdiam. Mereka merupakan mayoritas masyarakat urban yang mencoba peruntungan di kota, namun tidak memiliki skill atau kemampuan yang mumpuni sehingga menjadi gelandangan adalah konsekuensi yang mereka lakukan (Zainal Fadri, 2019: 5). Sedangkan pengemis memiliki makna sebagai orang yang melakukan praktik meminta-minta di depan dan tempat umum dengan melakukan berbagai macam metode untuk menarik perasaan iba dan rasa belas kasihan orang lain (Poerwadarwinta, 1990: 261).

Makna lain terkait dengan gelandangan dikemukakan oleh Sarlito W. Sarwono (2002: 49) yang mengartikan gelandangan sebagai orang-orang miskin yang tinggal di kota yang tidak mempunyai rumah tinggal. Orang-orang miskin yang tidak mempunyai rumah ini dianggap beban oleh pemerintah daerah karena orang-orang ini menyerap pendapatan dan beban dana pemerintah tanpa ada arus balik (feedback) seperti penyetoran pajak kepada pemerintah.

Sebagai salah satu kota yang menjadi tujuan destinasi wisata yang paling banyak dikunjungi di Indonesia, keberadaan gelandangan dan pengemis dinilai dapat menganggu citra Yogyakarta sebagai kota wisata di Indonesia.

Karena para wisatawan tersebut bisa jadi sangat terganggu dan risih atas keberadaan gelandangan dan pengemis. Masalah itulah yang menjadi salah satu faktor yang melatarbelakangi munculnya Peraturan Daerah No. 1 Tahun 2014 Tentang Penanganan Gelandangan dan Pengemis yang menjamur di Kota Yogyakarta. Peraturan Daerah Provinsi Daerah Istimewa Yogyakarta No. 1 Tahun 2014 tersebut berisi serangkaian aturan dan strategi dalam upaya menanggulangi gelandangan dan pengemis mulai dari tindakan preventif, koersif, rehabilitasi dan reintegrasi sosial (Perda DIY No.l, 2014). Namun dalam serangkaian strategi yang terdapat dalam perda tersebut, strategi koersif merupakan salah satu strategi yang paling kontroversial. Dalam strategi koersif terdapat pasal-pasal yang menghukum pengemis dan gelandangan serta pihak pemberi uang.

Hal tersebut dimaksudkan agar memutus mata rantai praktik menggelandang dan mengemis di tempat umum. Namun pemberian sanksi kepada pengemis, gelandangan dan pemberi uang bisa jadi terlalu berlebihan dan mengandung dilema tersendiri. Keberadaan pengemis dan gelandangan di tempat umum bisa jadi bukanlah kemauan melainkan keterpaksaan dalam bertahan hidup. Sedangkan masyarakat umum memberikan uang kepada gelandangan dan pengemis dengan sukarela karena ingin menolong.

Oleh karena itu, penulis merangkai beberapa rumusan masalah dari latar belakang serta landasan teori yang telah dipaparkan sebelumnya yakni; pertama, bagaimana strategi implementasi dari Peraturan Daerah ini ketika dieksekusi ke dalam 
realitas riil yang ada di masyarakat. Kedua, mengapa strategi koersif dan preventif menjadi sebuah dilema dalam penanggulangan gelandangan dan pengemis yang terdapat di dalam isi Peraturan Daerah Provinsi Yogyakarta No.l tahun 2014.

\section{Metode}

Metode penelitian yang digunakan dalam tulisan ini adalah penelitian deskriptif kualitatif. Metode penelitian kualitatif lumrahnya menggunakan model studi kasus. Dengan menggunakan model studi kasus diharapkan fenomena yang diteliti akan fokus sehingga data akan diperoleh secara mendalam dan spesifik. Di dalam metode penelitian kualitatif biasanya peneliti membutuhkan waktu yang relatif panjang (Bungin, 2008). Kehadiran peneliti secara langsung dalam penelitian kualitatif bersifat eksplisit dalam situasi yang terbatas dan melibatkan subjek jumlah yang relatif sedikit. Dengan demikian penelitian kualitatif umumnya bergelut dengan analisa tematik (Gumilar, 2005: 4).

Sedangkan terkait dengan metode pengumpulan data penelitian ini menggunakan metode campuran antara observasi serta dengan wawancara. Agar data diperoleh dengan baik di dalam penelitian ini, informan yang dipilih adalah informan yang memang merasakan langsung kebijakan Peraturan Daerah Provinsi Yogyakarta No. 1 Tahun 2014. Khusus yang terkait dengan analisis data penelitian ini menggunakan beberapa prosedur tahapan yang harus dilalui sebelum menyimpulkan data. Adapun tahapan tersebut adalah reduksi data kemudian dilanjutkan dengan penyajian data. Setelah data telah direduksi dan disajikan barulah data tersebut dapat disimpulkan.

Penelitian kualitatif secara efektif digunakan pada penelitian yang bertujuan menjawab konten pertanyaan why dan how terhadap sesuatu yang akan diteliti. Melalui pertanyaan itulah subtansi fundamental yang terkandung di dalam sesuatu yang akan diteliti dapat digali secara mendalam (Robert K. Yin, 2003: 12).

\section{Hasil dan Pembahasan}

Penanganan Gelandangan dan Pengemis di Yogyakarta

Gelandangan dan pengemis yang menghabiskan seluruh rangkaian kehidupannya di jalanan dikategorikan sebagai kelompok masyarakat Penyandang Masalah Kesejahteraan Sosial (PMKS). Dinas Sosial DIY mendefinisikan gelandangan sebagai orang-orang yang hidup dalam kondisi yang yang tidak sesuai dengan norma-norma kehidupan yang selayaknya dalam masyarakat, serta tidak memiliki mata pencaharian dan tempat tinggal yang tetap, sehingga kehidupan mereka cenderung mengembara di berbagai tempat-tempat umum. Sedangkan Nilam Hamidani Syaiful (2013:32) mendefinisikan pengemis sebagai sekelompok orang yang mendapatkan penghasilan dengan melakukan praktik meminta-minta di tempat umum dengan berbagai modus serta alasan agar mendapat belas kasihan orang-orang.

Jumlah gelandangan dan pengemis yang berada di DIY terus meningkat setiap tahunnya. Berdasarkan data yang dirilis oleh Dinas Sosial DIY dalam dua tahun terakhir menunjukkan adanya peningkatan. Pada tahun 2018, jumlah gelandangan mencapai 190 orang, pengemis sebanyak 134 orang. Pada tahun 2019, jumlah gelandangan naik menjadi 197 orang, dan pengemis naik ke angka 147 orang (Bappeda DIY, 2019). Tentunya dengan meningkatnya jumlah gelandangan dan pengemis tersebut, berdampak pada kenyamanan dan keamanan masyarakat. Mereka akan terganggu dengan keberadaan mereka di tempat-tempat publik. Kondisi ini dikhawatirkan dapat menurunkan citra 
Yogyakarta sebagai kota wisata, budaya, maupun kota pendidikan bagi para mahasiwa di Indonesia. Oleh karena itu, perlu dibuat sebuah kebijakan yang tepat sasaran serta strategi implementasi kebijakan yang efektif guna menanggulangi permasalahan gelandangan dan pengemis.

Sebagai upaya mengatasi permasalahan tersebut, ada beberapa pendekatan yang efektif digunakan. Salah satunya ialah pendekatan alternatif pembangunan sosial. Pendekatan ini bersifat top-down. Artinya, pembangunan bersifat dari atas ke bawah. Di sisi yang lain, bersifat bottom-up, yang berarti bahwa pembangunan bersifat dari bawah ke atas. Maksudnya ialah bahwa pembangunan sosial ditandai dengan adanya salah satu model pendekatan atau gabungan dari kedua model tersebut (M. Safi'i, 2007: 70).

Dari pengertian tersebut dapat ditarik sebuah benang merah yang menunjukkan bahwa penanganan masalah gelandangan dan pengemis dapat diselesaikan melalui dua arah, yakni pemerintah berperan dalam memproduksi suatu produk kebijakan dengan menerapkan strategi pengimplementasiannya. Kemudian masyarakat mendukung kebijakan tersebut, serta bersama-sama menekan angka gelandangan dan pengemis di Yogyakarta.

Adapun kebijakan yang dilakukan oleh Pemerintah DIY adalah dengan mengeluarkan Perda No. 1 Tahun 2014 tentang Penanganan Gelandangan dan Pengemis. Konten dalam Perda ini secara keseluruhan berisi tentang ragam penanganan yang akan dilakukan oleh Pemerintah DIY dalam mengatasi gelandangan dan pengemis dengan beragam pendekatan dan strategi yakni preventif, koersif, rehabilitatif dan reintegrasi sosial dengan melibatkan peran serta masyarakat. Secara sepintas, dengan adanya fenomena gelandangan dan pengemis seolah-olah memperlihatkan fenomena kemiskinan, persoalan kesejahteraan, serta adanya kaum marginal. Akan tetapi jika dianalisis secara mendalam, fenomena gelandangan dan pengemis bukan berangkat dari permasalahan yang penulis paparkan di atas. Anggapan tersebut tidak sepenuhnya benar, bahkan sama sekali tidak benar. Konstruksi berpikir serta orientasi para gelandangan dan pengemis di Yogyakarta bukan lagi seputar pemenuhan kebutuhan mendasar seperti makan dan minum dan lainnya, namun telah bergeser bahkan menyimpang. Sehingga mengemis dan menggelandang adalah sebuah profesi baru yang menjanjikan untuk pemenuhan gaya hidup (Bayu Mitra, 2018: 21).

Implementasi Peraturan Daerah DIY No. 1 Tahun 2014

jika mengacu kepada Van Meter dan van Horn yang dikutip oleh Grindle (1980:60) pengintegrasian antara tujuan dan hasil kebijakan membutuhkan jaringan dari berbagai macam pihak yang harus digandeng oleh pembuat kebijakan agar tujuan yang diharapkan dapat tercapai.

Bila diartikan secara luas, implementasi kebijakan merupakan salah satu tahapan dalam rangkaian proses kebijakan yang dilakukan setelah disahkanya sebuah undangundang ataupun peraturan oleh pemerintah. Implementasi kebijakan merupakan pelaksanaan undang-undang yang dilaksanakan oleh berbagai macam aktor yang terlibat dengan memperhatikan prosedur untuk secara bersama-sama berusaha untuk menjalankan sebuah kebijakan agar bisa menjawab masalah-masalah yang dihadapi oleh masyarakat banyak. Di dalam tahapan implementasi kebijakan juga dapat dilihat sejauh mana keluaran yakni output dan dampak yakni outcome yang dimiliki sebuah kebijakan (George C. Edwards, 1980: 104). 
Aspek keluaran atau output bisa dimaknai sebagai ketercapaian tujuan-tujuan yang telah diagendakan dalam sebuah kebijakan seperti sejauh mana penyerapan anggaran atau pengeluaran belanja bagi suatu program yang telah ditetapkan. Sedangkan dampak atau outcome adalah sejauh mana kebijakan yang dirumuskan dapat menyelesaikan permasalahan-permasalan riil yang ada di masyarakat serta sejauh mana dampak perubahan yang dirasakan oleh masyarakat terhadap adanya sebuah kebijakan yang ditetapkan oleh pemerintah. Sebagai contoh jika masalahnya adalah kemiskinan sejauh mana kebijakan yang dibuat tersebut dapat mengurangi jumlah masyarakat miskin dibandingkan dengan sebelum adanya kebijakan tersebut (Budi Winarno, 2014: 147-148).

Dalam konteks itulah, artikel ini akan mengeksplorasi dan melihat sejauh mana pengimplementasian Peraturan Daerah No. 1 Tahun 2014 ini khususnya dua aspek strategi dalam menanggulangi pengemis dan gelandangan. Dua aspek tersebut yakni preventif dan koersif.

1. Implementasi Strategi Koersif dalam Perda DIY No. 1 Tahun 2014

Strategi koersif merupakan salah satu strategi yang terdapat dalam Peraturan Daerah DIY tentang penanggulangan pengemis dan gelandangan. Upaya koersif dalam kebijakan ini dikenakan pada anggota masyarakat yang dianggap sebagai pelanggar dan dianggap tidak sesuai dengan yang sudah dituliskan dalam Peraturan Daerah Nomor 1 Tahun 2014 (Mutiaratih dan Sutoyo, 2017: 15)

Strategi penanganan ini dilakukan dengan berbagai macam cara yakni dengan melakukan pemidanaan terhadap pengemis dan gelandangan yang ketahuan mengemis dan menggelandang di tempat umum. Tidak hanya itu pemidanaan juga dilakukan kepada siapa saja pihak-pihak yang ketahuan memberikan uang maupun barang kepada pengemis dan gelandangan.

Penanganan dalam strategi koersif ini secara khusus dilakukan oleh Satuan Polisi Pamong Praja (Satpol-PP) DIY yang juga memiliki misi terkait dengan pelaksanaan penegakan peraturan daerah serta peraturan kepala daerah. Satpol-PP secara rutin melakukan razia di berbagai macam tempat yang dinilai sebagai sarang pengemis dan gelandangan khususnya pada tempat-tempat umum yang ramai seperti di kawasan Malioboro, kawasan alun-alun Yogyakarta dan kawasan Jalan Kusuma Negara (tribunnews.com, 2019).

Untuk lebih jelasnya, penulis telah menguraikan strategi koersif yang diterapkan oleh Pemerintah DIY dalam bentuk berikut ini:

Tabel 1.

Upaya Koersif

\begin{tabular}{|l|l|l|c|}
\hline $\begin{array}{l}\text { Landasan } \\
\text { Hukum }\end{array}$ & Kegiatan & \multicolumn{1}{|c|}{ Penjelasan } & Pelaksana \\
\hline & Penertiban & $\begin{array}{l}\text { Cara untuk mengatur dan menegakkan } \\
\text { aturan hukum dalam upaya } \\
\text { mewujudkan ketertiban dalam } \\
\text { masyarakat }\end{array}$ & Satpol PP \\
\hline
\end{tabular}




\begin{tabular}{|c|c|c|c|}
\hline \multirow{3}{*}{$\begin{array}{l}\text { Perda DIY } \\
\text { nomor } 1 \\
\text { tahun } \\
2014\end{array}$} & Penjangkauan & $\begin{array}{l}\text { Tindakan proaktif yang dilakukan oleh } \\
\text { petugas penjangkauan ke wilayah- } \\
\text { wilayah yang dijadikan tempat tinggal } \\
\text { gelandangan dan pengemis. }\end{array}$ & Dinas Sosial \\
\hline & Pembinaan & $\begin{array}{l}\text { kegiatan bimbingan mental sosial } \\
\text { yang dilakukan untuk membangun } \\
\text { pemikiran, sikap, perilaku pro sosial } \\
\text { yang sesuai dengan standar norma } \\
\text { hukum dan norma sosial yang } \\
\text { berlaku dalam masyarakat. } \\
\text { kontak awal dalam proses membina } \\
\text { hubungan sosial dengan } \\
\text { gelandangan dan pengemis }\end{array}$ & Dinas Sosial \\
\hline & Pelimpahan & 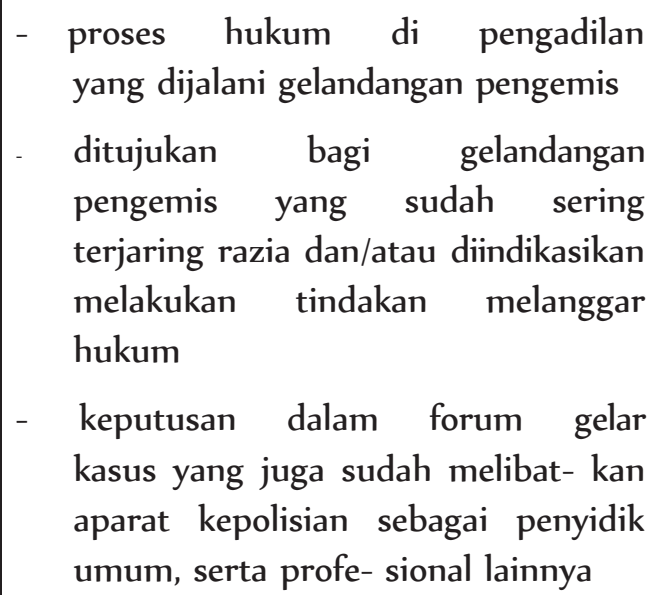 & Dinas Sosial \\
\hline
\end{tabular}

Dari beberapa kegiatan penertiban atau pembinaan yang dilakukan oleh Satpol-PP dalam menangani gelandangan dan pengemis, banyak ditemukan berbagai permasalahan. Salah satu aspek penting yang menjadi permasalahan adalah seringnya dalam kegiatan penertiban tersebut Satpol-PP mengabaikan aspek Hak Asasi Manusia. Diantaranya para pengemis yang terjaring razia penertiban tersebut tidak jarang mengalami kekerasan verbal dengan dicaci maupun dimaki dengan katakata makian yang disamakan dengan hewan (Anto, wawancara pribadi, 9 Desember 2019)

Bahkan ada juga yang mengalami kekerasan fisik berupa dorongan, pengejaran hingga penyeretan. Beberapa pengemis dan gelandangan mengalami penangkapan sewenang-wenang dan ditahan di kamp assessment tanpa proses hukum yang jelas. Ketika ditahan di camp assessment tidak mendapatkan fasilitas yang layak seperti kebersihan sanitasi, camp assesement juga tidak menyediakan kebutuhan khusus perempuan seperti pembalut wanita jika menstruasi. Selain itu, para pengemis dan gelandangan yang ditangkap tidak diberi kejelasan informasi kapan akan dibebaskan dan bagaimana alur atau prosedur pembebasannya (wordpress.com, 2016).

Akan sangat berbahaya sekali jika penegakan aturan dalam hal ini Perda No. 1 Tahun 2014 yang otoritasnya dimiliki oleh Satpol-PP mengabaikan Aspek HAM. 
Walaupun secara output atau keluaran penertiban yang dilakukan oleh Satpol PP tersebut dapat menurunkan kuantitas dari pengemis dan gelandangan.

Namun jika itu mengabaikan aspek HAM akan sia-sia karena aspek HAM merupakan aspek yang harus dijaga khususnya dalam setiap menjalankan pengimplementasian sebuah kebijakan. Terlebih jika menilik outcome atau keluaran, seluruh aspek yang terdapat dalam Peraturan Daerah penanggulangan pengemis dan gelandangan ini belum dilaksanakan dengan baik. Seperti buruknya manajemen dan fasilitas dalam camp assessment yang bisa berakibat terlanggarnya hak-hak yang dimiliki oleh setiap manusia termasuk hak pengemis dan gelandangan.

2. Implementasi Strategi Preventif dalam Perda DIY No. 1 Tahun 2014

Di dalam Peraturan Daerah Provinsi DIY tentang penanggulangan pengemis dan gelandangan ini, kewenangan pencegahan atau usaha preventif khususnya dalam pelayanan pelatihan keterampilan, magang dan perluasan kesempatan kerja diserahkan kepada Satuan Kerja Perangkat Daerah (SKPD) yang mempunyai tugas dan fungsi dibidang ketenagakerjaan (Perda DIY, Pasal 8: 2). Bila mengacu kepada isi Perda tersebut maka yang berwenang di dalam melakukan usaha preventif adalah Dinas Ketenagakerjaan Provinsi DIY. Salah satu upaya preventif dari Dinas Ketenagakerjaan DIY dalam menanggulangi pengemis dan gelandangan adalah dengan melaksanakan program pelatihan melalui Balai Latihan Kerja dan Pengembangan Produktivitas (BLKPP). Berikut penulis ulas strategi preventif Perda DIY No. 1 Tahun 2014 dalam tabel berikut ini

Tabel 2.

Upaya Preventif

\begin{tabular}{|c|c|c|c|}
\hline Landasan & Kegiatan & Penjelasan & Pelaksana \\
\hline \multirow{4}{*}{$\begin{array}{l}\text { Perda DIY } \\
\text { Nomor } 1 \\
\text { tahun } 2014\end{array}$} & Balai Latihan Kerja & $\begin{array}{lr}\text { Cara untuk } & \text { memberikan } \\
\text { pendidikan } & \text { dengan } \\
\text { memaksimalkan } & \text { keterampilan } \\
\text { PMKS } & \end{array}$ & $\begin{array}{l}\text { Dinas } \\
\text { Tenaga } \\
\text { Kerja }\end{array}$ \\
\hline & Pendampingan & $\begin{array}{l}\text { Tindakan pendampingan yang } \\
\text { dilakukan oleh fasilitator selama } \\
\text { dua bulan kepada PMKS sesuai } \\
\text { dengan bidangnya masing- } \\
\text { masing }\end{array}$ & Fasilitator \\
\hline & Pembinaan & 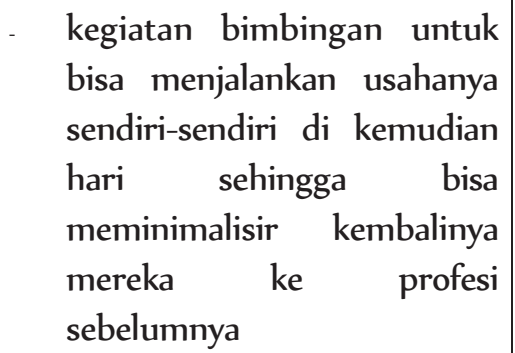 & $\begin{array}{l}\text { Dinas } \\
\text { Tenaga } \\
\text { Kerja }\end{array}$ \\
\hline & & - melakukan pelatihan- & \\
\hline
\end{tabular}




\begin{tabular}{|l|lr|r|}
\hline & pelatihan dasar dalam & \\
berwirausaha r serta & \\
memfasilitasi mereka sesuai & \\
& dengan minat dan & \\
& bakatnya. & \\
\hline
\end{tabular}

Pelatihan-pelatihan kerja menjadi penting untuk memberikan pendidikan yang dirancang secara terstruktur dan sistematis khususnya pendidikan dalam keterampilan bekerja kepada para anak didiknya. Harapannya dengan diberikannya pendidikan keterampilan tersebut, para peserta yang mengikuti pelatihan kerja di BLKPP dapat menjadi pekerja yang baik (well educated), pekerja yang terlatih (well trained) dan yang terakhir adalah melek atau menguasai informasi (well informed). Keberadaan BLKPP harus benar-benar dimanfaatkan oleh masyarakat calon pekerja karena di BLKPP ini masyarakat calon pekerja selain memperoleh pendidikan keterampilan namun juga dapat saling tukar informasi dan pengalaman dengan trainer ataupun dengan sesama peserta pelatihan (Aji Widiatmojo, 2018: 117).

Dilaksanakannya sebuah pendidikan dan pelatihan, salah satunya bertujuan untuk membekali pengetahuan dan keterampilan kerja khususnya bagi remaja maupun pemuda putus sekolah ataupun remaja dan pemuda yang baru lulus sekolah yang belum mempunyai keterampilan maupun keahlian untuk memasuki dunia kerja. Harapanya setelah menjalani masa pendidikan dan pelatihan tersebut para pemuda tersebut bisa menjalankan usaha sendiri ataupun bekerja dengan orang lain (Sunarto, 2006: 6). Sehingga dapat mengurangi atau meminimalisir kemungkinan untuk menjadi pengemis ataupun gelandangan. Terkait dengan pemberian keterampilan kepada peserta didik Balai Latihan Kerja dan Pengembangan Produktivitas menyediakan dan memfasilitasi berbagai macam pelatihan khususnya dalam bidang kejuruan yang terbagi ke dalam bidang otomotif, bahasa asing, listrik, tata niaga, perhotelan, bangunan, aneka kerajinan, elektronika, teknologi mekanik, menjahit dan membordir. Berbagai macam pelatihan di berbagai macam bidang tersebut dilakukan oleh fasilitator-fasilitator yang mempunyai kompetensi dan kapasitas di masing-masing bidang yang ditekuninya.

Masing-masing fasilitator memiliki jadwal sendiri-sendiri dalam menjalankan atau melaksanakan pendampingan setiap harinya (Nur, wawancara pribadi, 12 Desember 2019). Lama durasi pelatihan keterampilan di BLKPP Yogyakarta ini dilakukan kurang lebih selama 2 bulan lebih. Ketika para peserta telah mengikuti seluruh rangkaian pelatihan dan dinyatakan lulus maka secara otomatis akan secara resmi masuk ke dalam data peserta yang dimiliki oleh BLKPP Yogyakarta. Di dalam setiap pendaftaran peserta didik baru biasanya BLKPP menerima sekitar tiga puluhan peserta didik disetiap bidangnya. Namun biasanya para calon peserta didik lebih dan condong untuk memilih bidang pelatihan yang dirasa gampang untuk dipelajari misalnya bidang pelatihan keterampilan kerajinan yang menjadi bidang favorit dari para calon peserta didik (Siti, wawancara, 18 Desember 2019).

Dalam pelaksanaan pelatihan tersebut para peserta merasa sangat nyaman karena pelatihan dilaksanakan secara partisipatif dan komunikatif. Setiap peserta didik selalu diberikan kesempatan untuk memberikan interupsi atau pertanyaan 
kepada para fasililator jika menemui suatu kendala ataupun merasa kurang cocok dengan apa yang disampaikan oleh fasilitator. Sedangkan interaksi dengan sesama peserta didik terjalin dengan cukup bagus. Sesama peserta didik sangat aktif di dalam memberikan masukan satu dengan yang lainya di dalam pelaksanaan pelatihan (Gonet, wawancara pribadi, 18 Desember 2019).

Dilema kebijakan Publik dalam Perda DIY No. 1 Tahun 2014 antara Preventif dan Koersif Kebijakan publik merupakan serangkaian keputusan-keputusan yang memiliki keterkaitan dengan pilihan keputusan yang dilakukan oleh institusi maupun pejabat pemerintahan (Yahya Anggara, 2014: 7). Jika ditilik dari segi istilah kebijakan publik terdiri dari dua kata yakni kebijakan dan publik. Kata kebijakan disandarkan ke dalam bahasa Inggris policy yang diartikan dengan politik, siasat ataupun kebijaksanaan (Wojosasito, 1975: 60). Namun, ada juga yang mengartikan bahwa kebijakan berbeda dari segi istilah dengan kebijaksanaan, karena kebijaksanaan membutuhkan beraneka ragam pertimbangan-pertimbangan yang lebih jauh lagi, sedangkan kebijakan merupakan produk dari aturan-aturan yang dipertimbangkan sebelumnya (Muhammad Irfan Islamy, 1999: 130). Produk dari kebijakan tersebut berupa dokumen resmi seperti UndangUndang, Peraturan Pemerintah, Keputusan Presiden, Peraturan Menteri dan lain sebagainya.

Bentuk dari kebijakan publik sangatlah banyak, namun menurut Riant Nugroho (2009: 131) jika mengacu kepada model kontinental seperti Indonesia secara umum dapat dikelompokkan kedalam tiga kelompok yakni pertama, kebijakan publik yang bersifat mikro yang salah satunya sengaja mendasarkan kepada bidang-bidang tertentu seperti mengatur perdagangan dan inflasi yang berkaitan dengan unsur masyarakat. Kedua, kebijakan publik bersifat messo yang berbentuk penjelasan pelaksanaan seperti Peraturan menteri, Peraturan gubernur, Peraturan bupati/walikota maupun Surat Keputusan Bersama (SKB) antar menteri. Sedangkan yang ketiga, kebijakan bersifat mikro yang berisi pelaksanaan maupun implementasi kebijakan di atasnya. Bentuk kebijakannya berupa peraturan yang dibuat oleh pegawai di bawah menteri, gubernur, bupati/walikota.

Dalam konteks daerah, Peraturan Daerah merupakan salah satu produk kebijakan publik yang di produksi oleh pemerintah kabupaten, kota maupun provinsi. Keputusan pemerintah daerah dalam membuat sebuah Peraturan Daerah dimaksudkan untuk dapat mengelola atau mengendalikan pemerintahannya.

Dalam melaksanakan dan menghidupkan penyelenggaraan pemerintah daerah, kebijakan publik merupakan salah satu instrumen penting di dalam penentu kesuksesan segala aktivitas yang terkait dengan penyelenggaraan pemerintahan. Kebijakan publik dan hukum bahu membahu dalam menjadi pondasi dalam penyelenggaraan pemerintahan yang baik.

Adapun pembahasan terkait dengan kebijakan dan hukum mencakup dua hal yakni aspek keadilan terkait dengan kebutuhan masyarakat akan rasa adil dan aspek legalitas yang terkait dengan keputusan dari pemerintah yang sah sesuai prosedur (Edi Wibowo, 2004: 30-31).

Sebuah kebijakan publik lahir sebagai jawaban atas masalah yang dirasakan oleh masyarakat banyak dan bukan atas masalah pribadi atau individu. Sebuah masalah dapat dikatakan masalah publik harus terlebih dahulu dikategorisasikan dan perlu dibuat 
karakteristik-karakteristiknya. Secara sederhana pendefinisian masalah publik adalah masalah-masalah yang memiliki konsekuensi yang luas sampai kepada pihak yang tidak secara langsung terlibat. Sedangkan masalah yang hanya memiliki konsekuensi kepada satu atau beberapa orang yang terlibat secara langsung dapat dikatakan sebagai masalah pribadi atau individu (Budi Winarno, 2014: 72-73).

Dalam konteks Peraturan Daerah DIY No. 1 tahun 2014 keberadaan gelandangan dan pengemis dianggap sebagai masalah publik. Pengemis dan gelandangan di wilayah publik diasumsikan dapat menganggu ketertiban dan kenyamanan umum. Berbagai macam aktivitasnya dianggap tidak sinkron dengan norma, adat istiadat, maupun aturan yang dimiliki oleh masyarakat mayoritas. Segala aktivitasnya yang dianggap tidak sinkron dengan norma masyarakat tersebut meligitimasi sebagian masyarakat termasuk pemerintah untuk melabelinya sebagai penyakit masyarakat atau penyakit sosial (Kartini Kartono, 2003; 40).

Merebak serta maraknya pengemis dan gelandangan tidak bisa dilepaskan dari peristiwa industrialisasi dan urbanisasi yang terjadi di sebuah perkotaan. Industrialisasi yang hanya terjadi dalam ranah perkotaan yang menjanjikan berbagai macam pekerjaan membuat sebuah disparitas atau kesenjangan terutama dalam segi ekonomi antara wilayah perkotaan dan pedesaan.

Alih-alih mengembangkan dan memperhatikan sektor pertanian di pedesaan, Pemerintah justru mengabaikanya dan condong kepada industrialisasi yang menyebabkan urbanisasi besar-besaran di wilayah perkotaan (Manning dan Effendi, 1995: 11). Namun sayangnya, industrialisasi di perkotaan yang menjanjikan pekerjaan kepada masyarakat jumlahnya hanya terbatas dan tidak bisa mengakomodasi atau memenuhi permintaan pekerjaan kepada seluruh masyarakat.

$\mathrm{Hal}$ tersebut memunculkan adanya pengangguran yang menyebabkan masyarakat mencari alternatif pekerjaan maupun kegiatan untuk bertahan hidup. Mulai dari bekerja di sektor informal seperti pedagang kaki lima hingga berkegiatan di jalanan dengan mengamen maupun mengemis. Kegiatan di sektor informal tersebut dirasa sebagai penyelamat oleh sebagian masyarakat tersebut di tengah segala keterbatasan dalam hal keterampilan dan keahlian (Manning dan Effendi, 2003: 91).

Dalam melihat realitas gelandangan dan pengemis tersebut Peraturan Daerah DIY No. 1 tahun 2014 tersebut berupaya untuk menangani para pengemis dengan strategi preventif, koersif, rehabilitasi dan reintegrasi sosial. Namun dalam tulisan ini hanya akan membahas strategi preventif dan koersif karena jika strategi tersebut ditilik dari segi pencegahan dan penanganan kedua strategi tersebut sudah mewakili kedua strategi yang lainya yakni rehabilitasi dan reintegrasi sosial yang sama dengan koersif yakni bersifat penanganan.

Penanganan yang bersifat koersif menjadi problematik, karena di dalam Perda tersebut ditetapkan aturan pemidanaan terhadap para gelandangan dan pengemis dengan pemidanaan kurungan dan atau denda maksimal kisaran puluhan juta (Perda DIY, No. 1, 2014). Hukuman pemidanaan kurungan dan denda dirasa menjadi dilematis karena tujuan pemberian hukuman tersebut sebetulnya ingin memutus mata rantai praktik pengemis dan para gelandangan di jalanan. Namun jika di pandang pada sisi yang lainya keputusan penghukuman tersebut kurang bijak ketika pemerintah tidak melihat aspek historisitas dan penyebab keberadaan sebagian masyarakat menjadi pengemis dan gelandangan. 
Dimata pemerintah, kemunculan Peraturan Daerah No. 1 tahun 2014, khususnya dalam penanganan menggunakan strategi koersif ini tidak lepas dari semakin meningkatnya jumlah gelandangan dan pengemis di Yogyakarta. Menurut data yang dikeluarkan oleh Dinas Sosial DIY jumlah keseluruhan gelandangan dan pengemis yang terdapat di Yogyakarta pada tahun 2014 sebanyak 684 orang. Masing-masing terdiri atas gelandangan sebanyak 161 orang, pengemis 191 orang dan gelandangan psikotik sebanyak 296 orang (jogjadaily.com, 2016). Pemerintah merasa khawatir dengan semakin meningkatnya jumlah gelandangan dan pengemis karena dapat menganggu kenyamanan masyarakat dan bisa jadi juga turut dalam menurunkan citra yang dibangun oleh Yogyakarta sebagai kota wisata, budaya maupun pendidikan di Indonesia.

Terlebih lagi keberadaan pengemis dan gelandangan di Yogyakarta juga terindikasi digerakkan oleh mafia. Sebagian pengemis dan pengamen tersebut terindikasi melakukan praktik mengemis dan menggelandang bukan karena faktor kemiskinan melainkan dengan sengaja memanfaatkan kegiatan mengemis dan menggelandang sebagai profesi yang menguntungkan. Sebagian pengemis dan gelandangan tersebut sengaja diorganisir oleh mafia dengan sengaja di drop, di petakan dan ditempatkan pada tempat-tempat wisata yang ada di Yogyakarta. Tak jarang dari mereka sebetulnya memiliki fasilitas memadai di rumahnya. Namun ketika mengamen dan mengemis sudah menjadi profesi sehari-harinya karena menjanjikan penghasilan yang menguntungkan sebagian orang tersebut rela untuk berpenampilan buruk dengan mengenakan pakaian compang-camping (sindonews.com, 2019).

Sebagian para pengemis dan gelandangan juga memperhatikan dan memilih waktu yang tepat dalam mengemis dan menggelandang. Para gepeng tersebut sangat cermat dalam menentukan waktu karena ketepatan dalam memilih waktu dapat menentukan besar kecilnya pendapatan yang diperoleh dari mengamen dan mengemis. Tak jarang sebagian dari pengemis dan pengamen tersebut memanfaatkan momen seperti pada bulan Ramadan untuk melancarkan aksinya. Para pengamen dan pengemis tersebut melakukan aksinya pada bulan Ramadan karena beralasan ketika bulan Ramadan masyarakat pada umumnya cenderung mengeluarkan sedekah lebih banyak dari bulan-bulan biasanya, sehingga moment tersebut dimanfaatkan oleh pengemis (jogja.tribunnews.com, 2016).

Selain itu ada juga pengemis dan pengamen yang memilih waktu pada hari tertentu yakni hari jumat. Para pengamen dan pengemis tersebut memanfaatkan hari Jumat, karena pada hari Jumatlah sebagian besar masyarakat di Yogyakarta menjalankan ibadah wajib sholat Jumat diseluruh masjid yang ada di Yogyakarta. Para pengemis dan pengamen tersebut dengan sengaja berbondong-bondong menuju ke masjid untuk saling memperebutkan sedekah dari para jamaah sholat Jumat. Namun biasanya sebagian pengemis tersebut hanya memilih beberapa masjid saja yang dijadikan favorit untuk mengemis yakni masjid yang besar dan berlokasi di daerah kota atau daerah elit (Suparmi, wawancara pribadi, 13 Desember 2019). Dari serangkaian realitas itulah pemerintah DIY menggunakan rasionalisasi dan legitimasi penggunaan strategi koersif yang terdapat dalam perda No. 1 tahun 2014 tersebut.

Namun sebagian kalangan juga berfikiran bahwa strategi koersif tidak perlu dilaksanakan dan hanya cukup menerapkan strategi preventif saja. Aturan strategi preventif dinilai lebih efektif dan efisien dalam meminimalisir keberadaan pengemis dan gelandangan. Karena startegi preventif melakukan pencegahan pada akar dan sumber 
masalah para pengemis dan pengamen yakni kurangnya ketrampilan, pengetahuan dan informasi. Strategi preventif juga dinilai lebih memanusiakan manusia dibanding dengan strategi koersif yang bisa jadi dapat melanggar harkat dan martabat dari manusia.

Terlebih di dalam strategi koersif yang terdapat di dalam isi Peraturan Daerah DIY ini terdapat pasal yang sangat kontroversial yakni penghukuman dengan pemidanaan dan pemberian denda kepada setiap orang yang memberikan uang ataupun barang kepada pengemis atau pengamen (Perda DIY, Pasal 24: 5). Padahal masyarakat yang memberikan sesuatu baik uang maupun barang tersebut berniat baik yakni ingin membantu orang yang berkesusahan. Masyarakat yang berniat menolong tersebut memiliki simpati dan empati kepada para pengemis maupun pengamen tersebut namun justru dipidanakan.

Hal tersebut berbeda dengan strategi preventif yang lebih fokus kepada pemenuhan delapan aspek penting dalam penanggulangan pengamen dan gelandangan yakni pelatihan keterampilan, peningkatan derajat kesehatan, fasilitasi tempat tinggal, peningkatan pendidikan, penyuluhan dan edukasi masyarakat, pemberian informasi melalui baliho di tempat umum, bimbingan sosial dan yang terakhir adalah bantuan sosial (Perda DIY, Pasal 8)

Namun ada aspek penting yang harus diperhatikan dalam penerapan strategi preventif ini yakni karena membutuhkan biaya yang cukup besar untuk membangun infrastuktur sumber daya fisik maupun manusia dalam pengimplementasian delapan aspek tersebut. Ranah implementasi harus benar-benar dilaksanakan dengan baik dan benar.

Karena jika sampai terjadi sebuah kesalahan maupun penyelewengan dalam pengimplementasian delapan aspek penting tersebut biaya yang sudah dikeluarkan baik moril maupun materil akan terbuang sia-sia. Walaupun kedua pendekatan baik preventif maupun koersif sama-sama memiliki kelebihan dan kekurangan namun menurut hemat penulis pendekatan preventif harus diutamakan dan pertamakan dengan asumsi tindakan preventif lebih sedikit kelemahanya dan lebih manusiawi dibanding dengan strategi koersif yang memiliki aspek kontroversial seputar pemidanaan terhadap pengemis, gelandangan pemberi uang dan barang.

\section{Penutup}

Jika melihat Peraturan Daerah Provinsi Yogyakarta No. 1 tahun 2014 tentang Penanganan Gelandangan dan Pengemis terdapat empat aspek strategi yakni preventif, koersif, rehabilitasi dan reintegrasi sosial. Dari hasil pembahasan diatas ada sebuah refleksi dari implementasi Perda tersebut, yakni dilema antara strategi koersif maupun preventif. Strategi koersif memiliki aspek yang kontroversial yakni berupa pemidanaan terhadap pengemis dan gelandangan yang terciduk sedang melaksanakan aksinya ditempat umum. Ditambah setiap orang yang ketahuan petugas memberi uang kepada pengemis dan gelandangan juga dapat dikenai pemidanaan ataupun denda. Hal tersebut sungguh tidak elok jika tidak memperhatikan akar dari adanya pengemis dan gelandangan yang kebanyakan disebabkan oleh marak serta banyaknya kemiskinan dan pengangguran.

Namun pemidanaan pengemis dan gelandangan serta pemberi uang dan barang pengemis disatu sisi memiliki legitimasi karena adanya fakta bahwa banyak dari 
pengemis yang memang tidak mau bekerja dan memang mempunyai niat untuk mengemis karena merasa penghasilan dari mengemis cukup menggiurkan. Sebagian pengemis bahkan memiliki strategi dalam mengemis seperti memilih waktu dan tempat yang dianggap tepat yakni pada bulan Ramadan dan hari Jumat. Sedangkan untuk tempat para pengemis memilih tempat umum yang ramai diantaranya di kawasan Malioboro, Alun-Alun Yogyakarta hingga masjid-masjid besar yang terletak di lingkungan elit seperti Masjid Syuhada Kotabaru. Selain itu keberadaan pengemis dan gelandangan di Yogyakarta terindikasi diorganisir oleh mafia pengemis.

Sedangkan pada strategi preventif juga memiliki aspek yang harus diperhatikan yakni berupa biaya yang cukup besar. Biaya yang besar tersebut diperuntukkan untuk membangun berbagai macam sarana fisik maupun non fisik seperti pembangunan balai latihan kerja, penyediaan fasilitator pelatihan dan berbagai macam aspek untuk mendukung terciptanya para pekerja yang produktif dan inovatif. Mengimplementasikan strategi ini cukup besar.

Sedangkan pada ranah implementasi strategi koersif dan preventif memiliki aspek catatan yang harus diperhatikan. Pada implementasi strategi koersif, catatan yang harus diperhatikan yakni masih seringnya dalam penertiban yang dilakukan oleh Satpol PP mengabaikan dimensi hak asasi manusia. Satpol PP dengan sewenang-wenang melakukan kekerasan verbal seperti melakukan caci maki kepada para pengemis. Bahkan tak jarang para petugas Satpol PP tersebut seringkali juga mendorong hingga menyeret para pengemis. Sedangkan pada strategi preventif cacatan yang harus diperhatikan adalah pada perekrutan peserta BLKPP secara kuantitas masih sangat terbatas diperlukan penambahan kuota perekrutan peserta agar impian untuk meminimalisasi praktik mengemis dan menggelandang dapat terwujud.

Karena kedua strategi tersebut yakni preventif dan koersif sama-sama memiliki kelemahan dan kelebihan masing-masing maka penulis berpendapat bahwa strategi preventif harus diutamakan dan dipertamakan mengingat aspek kelemahanya lebih rendah dibandingkan dengan strategi koersif. Selain itu strategi preventif lebih utama karena dapat mengatasi akar atau hulu dari masalah dibanding strategi koersif yang baru mengatasi pada hilir masalah.

\section{Referensi}

Anggara, Yahya. 2014. Kebijakan Publik. Bandung: Penerbit Pustaka Setia.

Bungin, Burhan. 2008. Penelitian Kualitatif: Komunikasi, Ekonomi, Kebijakan Publik, dan Ilmu Sosial Lainya. Jakarta: Kencana Prenada Media Group.

Bappeda Yogyakarta. 2019. Penyandang Masalah Kesejahteraan Sosial dan Sarana Kesejahteraan Sosial diakses dalam http://bappeda.jogjaprov.go.id/dataku/data dasar/cetak/105-penyandang-masalahkesejahteraan-sosial-dan-sarana-kesejahteraan-sosial, diakses pada tanggal 12 Desember 2019.

Effendi dan Manning. 1995. Sumber Daya Manusia, Peluang Kerja dan Kemiskinan. Yogyakarta: Tiara Wacana. 
2003. Urbanisasi, Pengangguran dan Sektor

Informal di Kota. Jakarta: Gramedia.

Edwards, George C. 1980. Implementing Public Policy. Washington: Congressional Quartely lnc.

Fadri, Zainal. 2019. 'Upaya Penanggulangan Gelandangan dan Pengemis (Gepeng) Sebagai Penyandang Masalah Kesejahteraan Sosial (PMKS) Di Yogyakarta. Jurnal Komunitas: Pengembangan Masyarakat Islam. Vol. 10 No. 1, pp.5.

Grindle, Merilee S. 1980. Politics and Policy Implementation in The Third World. New Jersey: Pricenton University.

Islamy, Muhammad Irfan. 1999. Prinsip-prinsip Perumusan Kebijaksanaan Negara. Jakarta: Bumi Aksara.

Jannati, Mutiaratih Larasati dan Johannes Sutoyo. 2017. Hasil dan Dampak Upaya Koersif dalam Penegakan Peraturan Daerah, Daerah lstimewa Yogyakarta Nomor 1 Tahun 2014 Tentang Penanganan Gelandangan dan Pengemis. Jurnal Kriminologi Indonesia. Vol. 13 No. 1, pp.15.

Jogja Daily.com. 2015. Dalam https://jogjadaily.com/2014/07/targetkan-bebas-gepeng-pada2015-berikut-program-unggulan-dinsos-diy/, diakses pada tanggal 14 Desember 2019.

Kusuma, Bayu Mitra A. dan Theresia Octastefani. 2018. "Melawan Budaya Kemiskinan: Strategi Implementasi Perda Penangana Gepeng di Daerah lstimewa yogyakarta." Welfare, Vol. 1 No. l, pp. 21.

Kartono, Kartini. 2003. Patologi Sosial Il Kenakalan Remaja. Jakarta: PT Raja Grafindo Persada.

Poerwadarwinta. 1990. Kamus Besar Bahasa Indonesia. Jakarta: Balai Pustaka, 1990.

Sarwono, Sarlito. 2002. Psikologi Sosial: Individu dan Teori-teori Psikologi Sosial. Jakarta: Balai Pustaka.

Sunarto. 2006. Manajemen Pemasaran 2. Jakarta: Adityamedia.

Syaiful, Nilam Hamidani. 2013. Merebut Kewarganegaraan Inklusif, Yogyakarta: PolGov.

Safi'i, Muhammad. 2007. Strategi dan Implementsi Pembangunan Ekonomi Daerah: Perspektif Teoritik, Malang: Averroes Press.

Sindonews.com. 2017. Dalam https://daerah.sindonews.com/read/1148211/189/peneliti-ugmpengemis-di-yogya-digerakkan-oleh-mafia-1476791808, diakses pada tanggal 14 Desember 2019. 
Tribun Jogja.com. 2019. Dalam https://jogja.tribunnews.com/2019/05/25/kembali-gelarrazia-satpol-pp-diy-tertibkan-delapan-gelandangan-dan-pengemis, diakses pada tanggal 17 Desember 2019.

Widiatmojo, Aji. 2018. "Evaluasi Pelatihan English For The Office di Balai Latihan Kerja danPengembangan Produktifitas (BLKPP) Daerah Istimewa Yogyakarta." Jurnal Prodi Teknologi Pendidikan Vol 7 No 2, pp. 117.

Winarno, Budi. 2014 Kebijakan Publik: Teori, Proses dan Studi Kasus. Jakarta: CAPS.

Wordpress.com.

2016.

Dalam

https://kaukusperdagepengdiy.wordpress.com/2016/04/26/press-release-perda-gepengmembunuh-kami/, diakses pada tanggal 17 Desember 2019.

Wojosasito. 1975. Kamus Umum Inggris-Indonesia. Jakarta: Cypress.

Wibowo, Eddi. 2004. Hukum dan Kebijakan Publik. Yogyakarta: Yayasan Pembaharuan Administrasi Publik Indonesia.

Yin, Robert K. 2003. Case Study Research, California: Sage Publication. 